\title{
Systematic Review: \\ Psychological Interventions in Chronic Low Back Pain: A Systematic Review
}

\author{
Sajjad Saadat ${ }^{1} \mathrm{Q}$, Mozaffar Hosseininezhad $^{2^{*}} \mathbf{Q}$, Seyed Sepehr Khatami ${ }^{1} \mathrm{Q}$, Reza Ghasemi Jobaneh $^{3} \mathrm{Q}$ \\ 1. Neuroscience Research Center, School of Medicine, Guilan University of Medical Sciences, Rasht, Iran \\ 2. Department of Neurology, Neurosciences Research Center, School of Medicine, Guilan University of Medical Sciences, Rasht, Iran \\ 3. Department of Counseling, Faculty of Education \& Psychology, Shahid Chamran University of Ahvaz, Ahvaz, Iran
}

$\begin{aligned} & \text { Use your device to scan } \\ & \text { and read the article online }\end{aligned}$
Pain: A Systematic Review. Iran J Neurosurg. 2021; 7(2):67-74. http://dx.doi.org/10.32598/irjns.7.2.1
def:" http://dx.doi.org/10.32598/irjns.7.2.1

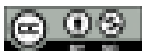

Article info:

Received: 05 Dec 2020

Accepted: 25 Mar 2021

Available Online: 01 Apr 2021

Keywords:

Psychology, Psychotherapy, Low back pain, Systematic review

\section{ABSTRACT}

Background and Aim: Chronic low Back Pain (CLBP) is one of the most common musculoskeletal disorders with possible psychological consequences for the patients. This study aimed to review all evidence on the effectiveness of psychological interventions in improving the mental status of people with CLBP and providing recommendations for future therapeutic interventions.

Methods and Materials/Patients: This systematic review was conducted on the articles published from January 2010 to December 2020. The keywords included "psychology", "intervention", "low back pain", "chronic disease", "quality of life", "empowerment", "psychotherapy", "psychological interventions", "clinical trials", and "randomized clinical trials" in the indexing databases of Magiran, PubMed, Scopus, and Google Scholar. Of the total 1740 articles found, 14 articles were selected for review.

Results: The results showed that Cognitive-Behavioral Therapy (CBT) and its combination therapies with mindfulness techniques played an influential role in improving psychological status and quality of life, and reducing pain perception in CLBP patients. The lack of RCT (randomized controlled trial) research and follow-up to assess long-term outcomes are the main limitations of the studies conducted in Iran.

Conclusion: It is recommended that psychological interventions be considered alongside medical therapies to improve CLBP patients' adjustment to chronic condition and their quality of life. Researchers and therapists should consider treatment programs based on RCT plans and long-term follow-up.

\section{*Corresponding Author:}

Mozaffar Hosseininezhad, MD.

Address: Department of Neurology, Neurosciences Research Center, School of Medicine, Guilan University of Medical Sciences, Rasht, Iran

Tel: +98 (13) 33322444

E-mail: hosseininezhadm@gmail.com 


\section{Highlights}

- Psychological interventions effectively impact the severity of pain and psychological symptoms in people with Chronic Low Back Pain (CLBP).

- Medical interventions combined with psychological interventions with a theoretical framework of mindfulness and meditation are the most effective treatment package for people with CLBP.

- Overlooking the randomized clinical trial project and lack of follow-up testing are important limitations in the studies conducted in Iran.

\section{Plain Language Summary}

Chronic Low Back Pain (CLBP) is one of the most common muscle disorders worldwide. The treatment of these patients requires mixed interventions by different specialists (neurosurgery, neurology, physiotherapy, and psychology). The quality of life of these patients decreases due to the experience of chronic ailment, and it is necessary to provide appropriate psychological interventions to empower them. In this systematic review, we found that Cognitive-Behavioral Therapy (CBT) and CBT therapies with mindfulness techniques have an influential role in improving psychological status and quality of life, and reducing pain perception in these patients. We suggest that more attention be paid to implementing RCT (Randomized Controlled Trial) projects and long-term follow-up in future studies in Iran.

\section{Introduction}

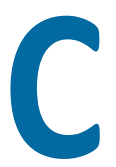

hronic Low Back Pain (CLBP) is one of the most common musculoskeletal disorders worldwide [1]. The disease is characterized by localized pain below the costal margin and above the inferior gluteal folds [2]. Chronic pain may persist in $10 \%$ to $20 \%$ of CLBP patients after medical and surgical treatment [3]. Unfortunately, the experience of pain is often accompanied by physical, psychological, social, and financial problems. Chronic pain is a leading cause of long-term disability worldwide [4]. It can have far-reaching consequences, such as psychological distress (e.g. depression, anxiety, and hopelessness), increased rates of pain-related disability, painrelated changes in cognition, and decreased quality of life [5]. These studies suggest that chronic conditions affect the quality of life in this group of patients. Besides attention to the morphological basis, biopsychosocial interventions should be administered to improve quality of life and adaptation to chronic illness $[6,7]$.

Incorporating psychological interventions into multidisciplinary approaches is beneficial for the treatment of CLBP. Psychological interventions can directly increase self-management knowledge and cope with stress, improve coping skills and emotion regulation, and facilitate adaptation to chronic ailments in people with CLBP [5]. Psychological interventions also increase patients' active participation, which reduces the rate of symptom recurrence and healthcare costs [8]. Previous research studies have shown that interventions such as Cognitive-Behavioral Therapy (CBT) [9-12] and other combination approaches with mindfulness [13-17] are highly effective in improving the physical and psychological symptoms of people with CLBP. Moreover, review studies have shown that psychological interventions significantly reduce anxiety, pain, and depression [18] and improve the quality of life [19] and general functioning [20] in people with CLBP.

In the literature review, many experimental studies have examined different psychological interventions to reduce pain symptoms and improve the psychological status and quality of life of these patients. Accordingly, it is necessary to review the literature, identify the most effective treatment models based on the best research designs and use them in Iranian research. This study aimed to review the effectiveness of all psychological interventions in improving the psychological status of people with CLBP and provide recommendations for future therapeutic interventions.

\section{Methods and Materials/Patients}

This study was conducted using a systematic review method in published studies from January 2010 to December 2020. Indexing databases such as Magiran, PubMed, Scopus, and Google Scholar were examined. To search for articles, we used the key terms of "psy- 
chology", "intervention", "low back pain", "chronic illness", "quality of life", "empowerment", "psychotherapy", "psychological interventions", "clinical trials", and "randomized clinical trial". In the PubMed database, the search was done based on the Medical Subject Heading (MeSH) keywords of "low back pain" by applying filters (All time from 2010 to 2020, Title/Abstract and Clinical Trial article type). Finally, a total of 857 articles were identified from this database. This search strategy was limited to Iran affiliation that only resulted in 75 articles. In other databases, an advanced search was performed based on the keyword "low back pain" and in combination with other keywords mentioned.

To thoroughly search the keywords, we used each keyword in combination with "low back pain". As a result, 1740 articles were found with the searched keywords in their titles or content. Two researchers reviewed the titles of the articles and the abstracts; then, many articles were removed from the review due to duplication, irrelevance, and lack of inclusion criteria.
Cohen's kappa coefficient was also calculated as optimal ( $\mathrm{k}=0.45$ ). Finally, 14 articles were selected and reviewed. Figure 1 shows the steps for reviewing the resources. The inclusion criteria for articles were as follows: published in a specific period, written in Persian or English, and conducted on patients with low back pain. Qualitative and single case articles, case reports, and articles based on pharmacological and medical interventions were excluded. To review the articles, we used the standard critique framework for health articles [21] and Sidant and Braden's approach for evaluating behavioral interventions [22]. To systematically review the articles, we considered the indicators of authors' last name and year of publication, type of intervention or theoretical framework, country of research, number of participants in the research, method of intervention, and outcome.

\section{Results}

In this study, 14 studies were reviewed, 7 of which were conducted in Iran. According to the results of Table 1, the

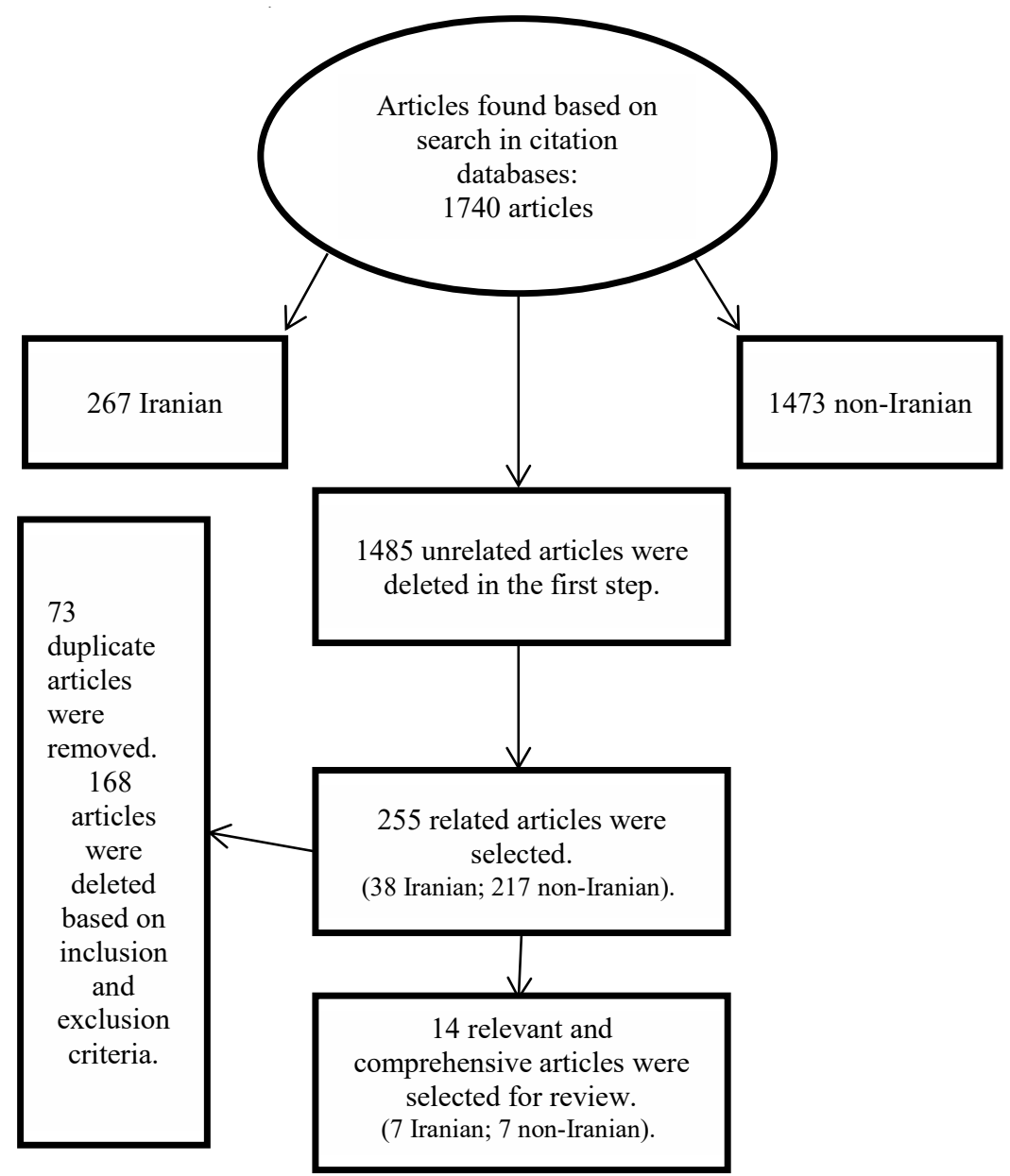

Figure 1. Steps for selecting articles 
Table 1. Characteristics of the included Iranian studies

\begin{tabular}{|c|c|c|c|c|c|c|c|}
\hline $\begin{array}{l}\text { Authors and } \\
\text { Year of Publi- } \\
\text { cation }\end{array}$ & Intervention/s & Country & Participants & Design & Follow-up & Consequences & $\begin{array}{c}\text { Confounding } \\
\text { Variables }\end{array}$ \\
\hline $\begin{array}{l}\text { Shokrgozar et } \\
\text { al. (2020) [9] }\end{array}$ & $\begin{array}{l}\text { CBT; } 10 \text { ses- } \\
\text { sions) }\end{array}$ & Iran & $\begin{array}{c}\text { CBT }(n=15) \\
\text { Control }(n=15)\end{array}$ & $\begin{array}{l}\text { Quasi-experi- } \\
\text { mental }\end{array}$ & None & $\begin{array}{l}\text { Positive effect on } \\
\text { perceived pain } \\
\text { and subjective } \\
\text { well-being }\end{array}$ & None \\
\hline $\begin{array}{l}\text { Jalali et al. } \\
\text { (2019) [10] }\end{array}$ & (CBT; 8 sessions) & Iran & $\begin{array}{c}\text { CBT }(n=20) \\
\text { Control }(n=20)\end{array}$ & $\begin{array}{l}\text { Quasi-experi- } \\
\text { mental }\end{array}$ & None & $\begin{array}{l}\text { Improved self- } \\
\text { efficacy and self- } \\
\text { discovery }\end{array}$ & None \\
\hline $\begin{array}{l}\text { Sobhani et al. } \\
\text { (2019) [17] }\end{array}$ & $\begin{array}{l}\text { (MBSR; } 8 \text { ses- } \\
\text { sions) }\end{array}$ & Iran & $\begin{array}{l}\text { MBSR }(n=20) \\
\text { Control }(n=20)\end{array}$ & $\begin{array}{l}\text { Quasi-experi- } \\
\text { mental }\end{array}$ & $\begin{array}{l}\text { One } \\
\text { month }\end{array}$ & $\begin{array}{l}\text { Decreased per- } \\
\text { ception of pain, } \\
\text { reduced depres- } \\
\text { sion, anxiety, and } \\
\text { stress symptoms }\end{array}$ & $\begin{array}{l}\text { Women with } \\
\text { postpartum- } \\
\text { induced } \\
\text { chronic low } \\
\text { back pain }\end{array}$ \\
\hline $\begin{array}{l}\text { Mousavi et al. } \\
\text { (2018) [23] }\end{array}$ & $\begin{array}{l}\text { (ACT; } 8 \text { ses- } \\
\text { sions) }\end{array}$ & Iran & $\begin{array}{c}\text { ACT }=(n=10) \\
\text { Control }(n=10)\end{array}$ & $\begin{array}{l}\text { Quasi-experi- } \\
\text { mental }\end{array}$ & None & $\begin{array}{l}\text { Improved quality } \\
\text { of life }\end{array}$ & $\begin{array}{l}\text { Participants } \\
\text { were women }\end{array}$ \\
\hline $\begin{array}{c}\text { Banth and } \\
\text { Didehdar } \\
\text { Ardebil (2015) } \\
{[16]}\end{array}$ & $\begin{array}{l}\text { (MBSR; } 8 \text { ses- } \\
\text { sions) }\end{array}$ & Iran & $\begin{array}{l}\text { MBSR }(n=39) \\
\text { Control }(n=48)\end{array}$ & Experimental & $\begin{array}{l}\text { One } \\
\text { month }\end{array}$ & $\begin{array}{l}\text { Reduced pain } \\
\text { severity and } \\
\text { improved quality } \\
\text { of life }\end{array}$ & $\begin{array}{l}\text { Aged } 30-45 \\
\text { years, } \\
\text { participants } \\
\text { were women }\end{array}$ \\
\hline $\begin{array}{l}\text { Abdolghadery } \\
\text { et al. (2014) } \\
{[15]}\end{array}$ & $\begin{array}{c}\text { (MBCT; } 8 \text { ses- } \\
\text { sions) } \\
\text { (CBT; } 8 \text { sessions) }\end{array}$ & Iran & $\begin{array}{c}\text { MBCT }(n=10) \\
\text { CBT }(n=10) \\
\text { Control }(n=10)\end{array}$ & Experimental & None & $\begin{array}{l}\text { Reduced sever- } \\
\text { ity of pain and } \\
\text { depression and } \\
\text { anxiety symptoms }\end{array}$ & None \\
\hline $\begin{array}{l}\text { Jonbozorgi et } \\
\text { al. (2013) [11] }\end{array}$ & $\begin{array}{l}\text { (CBT; } 12 \text { ses- } \\
\text { sions) }\end{array}$ & Iran & $\begin{array}{c}\text { CBT }(n=15) \\
\text { Control }(n=15)\end{array}$ & $\begin{array}{l}\text { Quasi-experi- } \\
\text { mental }\end{array}$ & None & $\begin{array}{c}\text { Decreased back } \\
\text { pain, depression, } \\
\text { anxiety, and stress } \\
\text { symptoms }\end{array}$ & $\begin{array}{l}\text { Aged } 20-45 \\
\text { years }\end{array}$ \\
\hline
\end{tabular}

CBT: Cognitive Behavioral Therapy; MBSR: Mindfulness-Based Stress Reduction; ACT: Acceptance and Commitment Therapy; MBCT: MindfulnessBased Cognitive Therapy

studies conducted in Iran were based on the theoretical framework of Cognitive-Behavioral Therapy (CBT) alone [9-11], CBT combined with mindfulness [15-17], and Acceptance and Commitment Therapy (ACT) [23]. The sample size in Iranian studies for intervention groups varied from $10[15,23]$ to 39 [16]. The studies mainly were quasi-experimental [9-11, 17, 23]; some were experimental [16], and only one study had a follow-up [17]. Moreover, psychological and physical outcomes such as reduction and severity of pain were considered in the Iranian studies. According to the results of Table 2, studies performed outside Iran, like those conducted in Iran, are mainly based on the theoretical framework of CBT $[12,24-26]$ or its combination with mindfulness and meditation $[13,14,25,27]$.

The sample size in non-Iranian studies ranged from 16 [27] to 464 [12]. The foreign studies were based on a randomized clinical trial design, except for one study
[27], which had a single-group design. A significant point in the non-Iranian researches was follow-up testing from one month [13] to 13 months [25].

\section{Discussion}

This study aimed to review the role of psychological interventions in people with Chronic Low Back Pain (CLBP). The results of our study showed that psychological interventions affect a wide range of psychological and pain-related outcomes. Cognitive-Behavioral Therapy (CBT) intervention is one of the most widely used interventions for CLBP, which effectively affects positive emotions, psychological well-being, and pain perception [9]. It improves self-efficacy and quality of life [10], reduces psychological distress (e.g. anxiety, depression, and stress) [11], pain perception and intensity [25], and depressive and anxiety symptoms [26]. 
Table 2. Characteristics of the included non-Iranian studies

\begin{tabular}{|c|c|c|c|c|c|c|c|}
\hline $\begin{array}{l}\text { Authors } \\
\text { and Year of } \\
\text { Publication }\end{array}$ & Intervention/s & Country & $\begin{array}{l}\text { Partici- } \\
\text { pants }\end{array}$ & Design & Follow-up & Consequences & $\begin{array}{l}\text { Confounding } \\
\text { Variables }\end{array}$ \\
\hline $\begin{array}{l}\text { Day et al. } \\
\text { (2019) [14] }\end{array}$ & $\begin{array}{c}\text { (MM: } 6 \text { ses- } \\
\text { sions) } \\
\text { (CT: } 6 \text { sessions) } \\
\text { (MBCT: } 6 \text { ses- } \\
\text { sions) }\end{array}$ & Australia & $\begin{array}{c}\text { MM }(n=23) \\
\text { CT (n=23) } \\
\text { MBCT } \\
(n=23)\end{array}$ & RCT & $\begin{array}{l}3 \text { and } 6 \\
\text { month }\end{array}$ & $\begin{array}{l}\text { Improvements in pain } \\
\text { interference, pain intensity, } \\
\text { physical function, and de- } \\
\text { pression }\end{array}$ & $\begin{array}{l}\text { Participants } \\
\text { were taking } \\
\text { medications. }\end{array}$ \\
\hline $\begin{array}{l}\text { Zgierska et } \\
\text { al. (2016) } \\
{[24]}\end{array}$ & $\begin{array}{c}\text { (M-CBT: } 8 \text { ses- } \\
\text { sions) }\end{array}$ & $\begin{array}{l}\text { United } \\
\text { States }\end{array}$ & $\begin{array}{l}\text { M-CBT } \\
(n=21) \\
\text { Control } \\
(n=14)\end{array}$ & $\mathrm{RCT}$ & $\begin{array}{l}2 \text { and } 6 \\
\text { months }\end{array}$ & Reduced pain severity & $\begin{array}{l}\text { All par- } \\
\text { ticipants } \\
\text { received } \\
\text { routine care } \\
\text { of CLBP. }\end{array}$ \\
\hline $\begin{array}{l}\text { Cherkin et } \\
\text { al. (2016) } \\
\quad[25]\end{array}$ & $\begin{array}{l}\text { CBT: } 8 \text { sessions) } \\
\text { (MBCT: } 8 \text { ses- } \\
\text { sions) }\end{array}$ & $\begin{array}{l}\text { United } \\
\text { States }\end{array}$ & $\begin{array}{c}\text { MBSR } \\
(n=116) \\
\text { CBT }(n=113) \\
\text { Control } \\
(n=113)\end{array}$ & $\mathrm{RCT}$ & $\begin{array}{l}4 \text { and } 13 \\
\text { months }\end{array}$ & $\begin{array}{l}\text { Improvement in back pain } \\
\text { and functional limita- } \\
\text { tions and no significant } \\
\text { differences in outcomes } \\
\text { between MBSR and CBT }\end{array}$ & None \\
\hline $\begin{array}{l}\text { Michalsen } \\
\text { et al. (2016) } \\
{[13]}\end{array}$ & $\begin{array}{l}\text { (Meditation: } 8 \\
\text { sessions) }\end{array}$ & $\begin{array}{l}\text { Ger- } \\
\text { many }\end{array}$ & $\begin{array}{l}\text { Meditation } \\
(n=32) \\
\text { Exercise } \\
(n=36)\end{array}$ & $\mathrm{RCT}$ & $\begin{array}{l}\text { One month } \\
\text { and } 2 \\
\text { months }\end{array}$ & $\begin{array}{l}\text { There was a significant } \\
\text { decrease in pain score in } \\
\text { the exercise group and } \\
\text { stress score in the medita- } \\
\text { tion group }\end{array}$ & None \\
\hline $\begin{array}{l}\text { Pincus et al. } \\
(2015) \text { [26] }\end{array}$ & $\begin{array}{l}\text { (CCBT: } 8 \text { ses- } \\
\text { sions) }\end{array}$ & England & $\begin{array}{c}\text { CCBT } \\
(n=45) \\
\text { Physiothera- } \\
\text { py }(n=44)\end{array}$ & $\mathrm{RCT}$ & $\begin{array}{l}3 \text { and } 6 \\
\text { months }\end{array}$ & $\begin{array}{l}\text { CCBT compared to phys- } \\
\text { iotherapy, in the long run, } \\
\text { has played an influential } \\
\text { role in improving the qual- } \\
\text { ity of life and reducing the } \\
\text { symptoms of depression } \\
\text { and anxiety. }\end{array}$ & None \\
\hline $\begin{array}{l}\text { Schütze et } \\
\text { al. (2014) } \\
{[27]}\end{array}$ & $\begin{array}{l}\text { (MBFT: } 8 \text { ses- } \\
\text { sions) }\end{array}$ & Australia & $\begin{array}{l}\text { MBFT } \\
(n=16)\end{array}$ & $\begin{array}{l}\text { Single group } \\
\text { repeated } \\
\text { measures }\end{array}$ & 6 months & $\begin{array}{l}\text { Catastrophic reduction of } \\
\text { pain, role limitations due to } \\
\text { physical condition and de- } \\
\text { pression, and improvement } \\
\text { of physical function }\end{array}$ & None \\
\hline $\begin{array}{l}\text { Lamb et al. } \\
(2010) \text { [12] }\end{array}$ & (CBT; 6 sessions) & England & $\begin{array}{l}\text { CBT }(n=468) \\
\text { Control } \\
(n=233)\end{array}$ & $\mathrm{RCT}$ & $\begin{array}{l}3,6 \text {, and } 12 \\
\text { months }\end{array}$ & $\begin{array}{c}\text { Reduced severity of chronic } \\
\text { pain and improved quality } \\
\text { of life }\end{array}$ & None \\
\hline
\end{tabular}

MM: Mindfulness Meditation; CT: Cognitive Therapy; MBCT: Mindfulness-Based Cognitive Therapy; RCT: Randomized Controlled Trial; M-CBT: Meditation, and Cognitive Behavioral Therapy; CCBT: Contextual Cognitive Behavioral Therapy; MBFT: Mindfulness-Based Functional Therapy

By learning cognitive reappraisal and emotion regulation, the intervention groups could generate positive emotions and modulate negative emotions, which directly contributed to reducing their psychological distress [28]. Learning the main components of this treatment (e.g. imagination, exposure, and cognitive restructuring) are also essential factors in reducing stress and anxiety. In addition to these components, cognitive restructuring training can affect patients' perception of pain and reduce their helplessness [25].
In recent years, the dominance of third-wave behavioral therapy has been observed in research on the health and empowerment of chronically ill patients. Meanwhile, the focus on mindfulness and the application of meditation and relaxation techniques through the combination of CBT has led to the formation of new treatment models such as Mindfulness-Based Stress Reduction (MBSR) and Mindfulness-Based Cognitive Therapy (MBST) [29, 30]. Stand-alone therapies such as Acceptance and Commitment Therapy (ACT) have also been welcomed by researchers in the field of chronic pain [31]. Our study has shown that these therapies are effective in 
reducing pain perception, stress, anxiety, and depression $[13,15,17]$, improving quality of life $[16,23,26]$, physical function and pain reduction [14], and pain relief [25].

Mindfulness is the common denominator of several complementary therapies that have originated in the Buddhist spiritual tradition and are integrated into behavioral therapy approaches [32]. Mindfulness is a state of consciousness described as momentary awareness without judgment and is a way to accept and trust personal experiences [33]. Therefore, mindfulness-based therapies involve training to maintain mindfulness during routine activities in daily life and an acceptance of personal moods and emotions without judgment [34]. Because CLBP patients in these therapies can accept their negative emotions related to pain without judgment, this treatment can effectively reduce patients' psychological symptoms and pain perception.

In reviewing the selected research, some points can be considered that may help improve the quality of future studies. The main criticisms are related to studies conducted in Iran. All of them were conducted using quasi-experimental and experimental methods without considering randomization and blinding. In other words, no research was found in this field based on RCT design $[9-11,15,17,23]$. Also, in the studies conducted in Iran, except for one study [9], no follow-up test was conducted. Using the RCT research design and conducting follow-up tests after one [13] to 13 months [25] emphasizes the value of research conducted abroad and provides more reliable results. Our suggestion for future studies in Iran is to take an effective step to promote clinical research by developing the RCT design and conducting follow-up tests. In most studies conducted in Iran and abroad, confounding variables such as age, gender, drug use, and history of spinal surgery have not been reported, which makes the generalization of the results difficult.

\section{Conclusion}

Our studies showed that CBT combination therapy with mindfulness played an influential role in improving psychological symptoms, quality of life, and reducing pain perception in CLBP patients. Given that the physical and psychological consequences of CLBP are highly correlated, it is suggested that psychological interventions be used in addition to physical interventions and surgeries to reduce the severity and perception of pain and psychological symptoms such as anxiety and depression.

\section{Ethical Considerations}

\section{Compliance with ethical guidelines}

There is no animal or human research reported in this study so there was no need for ethics board approval.

Funding

This research did not receive any grant from funding agencies in the public, commercial, or non-profit sectors.

Authors' contributions

All authors contributed equally to performing the project and preparing the manuscript.

Conflict of interest

There is no conflict of interest concerning this study.

\section{References}

[1] Ikemoto T, Miki K, Matsubara T, Wakao N. Psychological treatment strategy for chronic low back pain. Spine Surgery and Related Research. 2019; 3(3):199-206. [DOI:10.22603/ ssrr.2018-0050] [PMID] [PMCID]

[2] Liao ZT, Pan YF, Huang JL, Huang F, Chi WJ, Zhang $\mathrm{KX}$, et al. An epidemiological survey of low back pain and axial spondyloarthritis in a Chinese Han population. Scandinavian Journal of Rheumatolog. 2009; 38(6):455-9. [DOI:10.3109/03009740902978085] [PMID]

[3] Inoue S, Kamiya M, Nishihara M, Arai YCP, Ikemoto T, Ushida T. Prevalence, characteristics, and burden of failed back surgery syndrome: The influence of various residual symptoms on patient satisfaction and quality of life as assessed by a nationwide Internet survey in Japan. Journal of Pain Research. 2017; 10:811-23. [DOI:10.2147/JPR.S129295] [PMID] [PMCID]

[4] Hruschak V, Cochran G. Psychosocial and environmental factors in the prognosis of individuals with chronic pain and comorbid mental health. Social Work in Health Care. 2017; 56(7):573-87. [DOI:10.1080/00981389.2017.1326074] [PMID]

[5] Roditi D, Robinson ME. The role of psychological interventions in the management of patients with chronic pain. Psychology Research and Behavior Management. 2011; 4:41-9. [DOI:10.2147/PRBM.S15375] [PMID] [PMCID]

[6] Kikuchi S. The recent trend in diagnosis and treatment of chronic low back pain. Spine Surgery and Related Research. 2017; 1(1):1-6. [DOI:10.22603/ssrr.1.2016-0022] [PMID] [PMCID] 
[7] Kamper SJ, Apeldoorn AT, Chiarotto A, Smeets RJEM, Ostelo RWJG, Guzman J, et al. Multidisciplinary biopsychosocial rehabilitation for chronic low back pain: Cochrane systematic review and meta-analysis. BMJ. 2015; 350:h444. [DOI:10.1136/bmj.h444] [PMID] [PMCID]

[8] Coakley R, Wihak T. Evidence-based psychological interventions for the management of pediatric chronic pain: New directions in research and clinical practice. Children. 2017; 4(2):9. [DOI:10.3390/children4020009] [PMID] [PMCID]

[9] Shokrgozar A, Sepahmansour M, Emamipour S, Salehi M. [The effectiveness of cognitive-behavioral intervention on pain perception and subjective well-being in patients with chronic low back pain (Persian)]. The Neuroscience Journal of Shefaye Khatam. 2020; 8(4):12-9. [DOI:10.29252/shefa.8.4.12]

[10] Jalali ZM, Farghadani A, Ejlali-Vardoogh M. Effect of cognitive-behavioral training on pain self-efficacy, self-discovery, and perception in patients with chronic low-back pain: A quasi-experimental study. Anesthesiology and Pain Medicine. 2019; 9(2):e78905. [DOI:10.5812/aapm.78905] [PMID] [PMCID]

[11] Jonbozorgi M, Golchin N, Alipour A, Agah Heris M. [The effectiveness of group cognitive-behavior therapy on decreasing severity of pain and psychological distressamong women with chronic back pain (Persian)]. Iranian Journal of Psychiatry and Clinical Psychology. 2013; 19(2):102-8. http:/ /ijpcp. iums.ac.ir $/$ browse.php?a_id=2043\&sid=1\&slc_lang=en

[12] Lamb SE, Hansen Z, Lall R, Castelnuovo E, Withers EJ, Nichols V, et al. Group cognitive behavioural treatment for low-back pain in primary care: A randomised controlled trial and cost-effectiveness analysis. The Lancet. 2010; 375(9718):916-23. [DOI:10.1016/S0140-6736(09)62164-4] [PMID]

[13] Michalsen A, Kunz N, Jeitler M, Brunnhuber S, Meier L, Lüdtke R, et al. Effectiveness of focused meditation for patients with chronic low back pain- A randomized controlled clinical trial. Complementary Therapies in Medicine. 2016; 26:79-84. [DOI:10.1016/j.ctim.2016.03.010] [PMID]

[14] Day MA, Ward LC, Ehde DM, Thorn BE, Burns J, Barnier A et al. A pilot randomized controlled trial comparing mindfulness meditation, cognitive therapy, and mindfulness- based cognitive therapy for chronic low back pain. Pain Medicine. 2019; 20(11):2134-48. [DOI:10.1093/pm/pny273] [PMID]

[15] Abdolghadery M, Kafee M, Saberi A, Aryapouran S. [The effectiveness of Mindfulness-Based Cognitive Therapy (MBCT) and Cognitive Behavior Therapy (CBT) on decreasing pain, depression and anxiety of patients with chronic low back pain (Persian)]. The Journal of Shahid Sadoughi University of Medical Sciences. 2014; 21(6):795-807. http://jssu.ssu. ac.ir/article-1-2533-en.html

[16] Banth S, Didehdar Ardebil M. Effectiveness of mindfulness meditation on pain and quality of life of patients with chronic low back pain. International Journal of Yoga. 2015; 8(2):128-33. [DOI:10.4103/0973-6131.158476] [PMID] [PMCID]

[17] Sobhani E, Babakhani N, Alebouyeh MR. [The effectiveness of mindfulness-based stress reduction on the depression, anxiety, stress, and pain perception in females with obstructed labour-induced chronic low back pain (Persian)]. Iranian Journal of Psychiatry and Clinical Psychology. 2019; 25(3):266-77. [DOI:10.32598/ijpcp.25.3.266]
[18] Jandaghi G, Firoozi M, Zia-Tohidi A. Psychological interventions for depression and anxiety: A systematic review and meta-analysis of Iranian chronic pain trials. Health Promotion Perspectives. 2020; 10(3):180-91. [DOI:10.34172/hpp.2020.31] [PMID] [PMCID]

[19] Hoffman BM, Papas RK, Chatkoff DK, Kerns RD. Metaanalysis of psychological interventions for chronic low back pain. Health Psychology. 2007; 26(1):1-9. [DOI:10.1037/02786133.26.1.1] [PMID]

[20] van Tulder MW, Ostelo RWJG, Vlaeyen JWS, Linton SJ, Morley SJ, Assendelft WJJ. Behavioural treatment for chronic low back pain. The Cochrane Database of Systematic Reviews. 2000; 26(2):CD002014. [DOI:10.1002/14651858.CD002014]

[21] Yarmohammadian MH, Mohammadi E, Movahedi F. [Standards for writing review articles (Persian)]. Health Information Management. 2012; 8(8):1226-34. http://him.mui. ac.ir/index.php/him/article/view/543

[22] Closs SJ. >Evaluating nursing interventions. A theorydriven approach by S. Sidani \& C.J. Braden. Sage, London, 1998, 190 pages, US 46, ISBN 076190316 X. Journal of Advanced Nursing. 1999; 29(1):267. [DOI:10.1046/j.13652648.1999.0885j.x]

[23] Mousavi SM, Mujembari AK, Hassani Abharian $P$ Pashang S. Effectiveness of Acceptance and Commitmentbased Therapy (ACT rehab) on quality of life, severity and duration of pain; in women with chronic low back pain. Iranian Rehabilitation Journal. 2018; 16(1):103-10. [DOI:10.29252/ nrip.irj.16.1.103]

[24] Zgierska AE, Burzinski CA, Cox J, Kloke J, Stegner A, Cook DB, et al. Mindfulness meditation and cognitive behavioral therapy intervention reduces pain severity and sensitivity in opioid-treated chronic low back pain: Pilot findings from a randomized controlled trial. Pain Medicine. 2016; 17(10):1865-81 [DOI:10.1093/pm/pnw006] [PMID] [PMCID]

[25] Cherkin DC, Sherman KJ, Balderson BH, Cook AJ, Anderson ML, Hawkes RJ, et al. Effect of mindfulness-based stress reduction vs cognitive behavioral therapy or usual care on back pain and functional limitations in adults with chronic low back pain: A randomized clinical trial. JAMA. 2016; 315(12):1240-9. [DOI:10.1001/jama.2016.2323] [PMID] [PMCID]

[26] Pincus T, Anwar S, McCracken LM, McGregor A, Graham L, Collinson M, et al. Delivering an Optimised Behavioural Intervention (OBI) to people with low back pain with high psychological risk; Results and lessons learnt from a feasibility randomised controlled trial of Contextual Cognitive Behavioural Therapy (CCBT) vs. Physiotherapy. BMC Musculoskeletal Disorders. 2015; 16:147. [DOI:10.1186/s12891015-0594-2] [PMID] [PMCID]

[27] Schütze R, Slater H, O'Sullivan P, Thornton J, Finlay-Jones A, Rees CS. Mindfulness-based functional therapy: A preliminary open trial of an integrated model of care for people with persistent low back pain. Frontiers in Psychology. 2014; 5:839. [DOI:10.3389/fpsyg.2014.00839] [PMID] [PMCID]

[28] Mariano TY, Urman RD, Hutchison CA, Jamison RN, Edwards RR. Cognitive Behavioral Therapy (CBT) for subacute low back pain: A systematic review. Current Pain and Headache Reports. 2018; 22(3):15. [DOI:10.1007/s11916-018-0669-5] [PMID] 
[29] Merkes M. Mindfulness-based stress reduction for people with chronic diseases. Australian Journal of Primary Health. 2010; 16(3):200-10. [DOI:10.1071/PY09063] [PMID]

[30] Fjorback LO, Arendt M, Ornbøl E, Fink P, Walach H. Mindfulness-based stress reduction and mindfulness-based cognitive therapy: A systematic review of randomized controlled trials. Acta Psychiatrica Scandinavica. 2011; 124(2):102-19. [DOI:10.1111/j.1600-0447.2011.01704.x] [PMID]

[31] McCracken L. Mindfulness and acceptance in behavioral medicine: Current theory \& practice. Oakland: New Harbinger Publications; 2011. https://books.google.com/ books?id=NcP37_rcW5kC\&printsec=frontcover\&dq

[32] Baer RA. Mindfulness training as a clinical intervention: A conceptual and empirical review. Clinical Psychology: Science and Practice. 2003; 10(2):125-43. [DOI:10.1093/clipsy/bpg015]

[33] Baer RA. Mindfulness-based treatment approaches: Clinician's guide to evidence base and applications. Amsterdam: Elsevier; 2015. https://books.google.com/ books?id=4NrK3IGkOg8C\&dq

[34] Kabat-Zinn J. Wherever you go, there you are: Mindfulness meditation in everyday life. New York: Hachette Books; 2005. https:// books.google.com/books?id=dQ4RAQAAIAAJ\&q 